\title{
Selective oestrogen receptor (ER) modulators reduce microglia reactivity in vivo after peripheral inflammation: potential role of microglial ERs
}

\author{
Silvia Tapia-Gonzalez, Paloma Carrero, Olga Pernia, Luis M Garcia-Segura and Yolanda Diz-Chaves \\ Instituto Cajal, CSIC, Avenida Doctor Arce 37, E-28002 Madrid, Spain \\ (Correspondence should be addressed to L M Garcia-Segura; Email: Imgs@cajal.csic.es)
}

\begin{abstract}
It has been previously reported that the neuroprotective hormone oestradiol reduces microglia inflammatory activity. The objective of this study was to test whether two selective oestrogen receptor modulators, tamoxifen and raloxifene, modulate in vivo the activation of microglia induced by the peripheral administration of lipopolysaccharide (LPS). Activation of microglia was assessed in the white matter of the cerebellum using immunoreactivity for major histocompatability complex-II. Oestradiol, tamoxifen and raloxifene decreased microglia activation induced by LPS in male and ovariectomized female rats, although the doses of oestradiol that were effective in decreasing microglia reactivity were not the same in both sexes. Tamoxifen reduced microglia activation in all experimental groups at all doses tested $(0.5-2 \mathrm{mg} / \mathrm{kg}$ b.w.) while raloxifene lost its anti-inflammatory activity at the higher dose tested $(2 \mathrm{mg} / \mathrm{kg}$ b.w). In
\end{abstract}

addition, raloxifene had per se a moderate pro-inflammatory activity in the brain of control female rats and its antiinflammatory activity was partially impaired in female animals after 1 month of deprivation of ovarian hormones. Spots of oestrogen receptor (ER)- $\alpha$ immunoreactivity were detected in the soma and cell processes of microglia. Treatment with LPS, oestradiol or tamoxifen induced an increase of ER- $\alpha$ immunoreactive spots in the perikaryon of microglia, while oestradiol antagonized the effect of LPS. The results indicate that some oestrogenic compounds decrease brain inflammation by a mechanism that may involve ERs expressed by microglia. The findings support the potential therapeutic role of oestrogenic compounds as protective anti-inflammatory agents for the central nervous system.

Journal of Endocrinology (2008) 198, 219-230

\section{Introduction}

The central nervous system is a target for the ovarian hormone oestradiol, a key regulator of reproductive physiology. Oestradiol acts in different regions of the brain and the spinal cord controlling neuroendocrine secretions, reproductive behaviours and non-reproductive events, modulating synaptic function and plasticity, and affecting mood and cognition (Fink et al. 1996, McEwen et al. 1997, Woolley 2007). In addition, oestradiol is a neuroprotective factor that promotes neuronal survival and tissue integrity in different experimental models of neurodegeneration (Garcia-Segura et al. 2001, Maggi et al. 2004, Suzuki et al. 2006).

Recent studies suggest that at least part of the neuroprotective effects of oestradiol may be exerted by reducing brain inflammation acting on microglia. Oestradiol has been shown to inhibit the expression of inflammatory mediators by microglia in vitro (Bruce-Keller et al. 2000, 2001, Drew \& Chavis 2000, Vegeto et al. 2001, Baker et al. 2004, Dimayuga et al. 2005) and to reduce microglia reactivity in vivo in different models of brain inflammation (Vegeto et al. 2003,
2006) and brain injury (Barreto et al. 2007). These actions may be highly relevant for the neuroprotective actions of the hormone. Activation of microglia is a normal response from neural tissue to cope with infections and neurodegeneration and is oriented to protect neural tissue. However, exaggerated and chronic activation of microglia may lead to neurotoxicity and may be detrimental for neural tissue (Thomas 1992, Streit et al. 1999, Polazzi \& Contestabile 2002, Depino et al. 2003, Kim \& de Vellis 2005, Marchetti \& Abbracchio 2005, Minghetti 2005, Suzumura et al. 2006, Block et al. 2007). Therefore, the regulation of the response of microglial cells to inflammation may represent a therapeutic approach to control neurodegeneration.

Oestrogen receptors (ERs) are candidate targets for possible neuroprotective and anti-inflammatory therapies based on oestrogen actions. The activity of ERs is regulated by their association with transcriptional cofactors that have a tissue- or cell-specific expression (Klinge 2000, McKenna \& O'Malley 2002, Belandia \& Parker 2003). This association depends on the three-dimensional conformation of the receptors (Norris et al. 1999), which is modified by different oestrogenic ligands 
(Brzozowski et al. 1997, Paige et al. 1999, Pike 2006). Therefore, several ER ligands, known as selective ER modulators (SERMs), are able to exert tissue- and cellular-specific inductions or repressions of the activity of ERs, acting as ER agonists in some tissues and as antagonists in others. SERMs may therefore represent an alternative to oestradiol for the treatment or prevention of neurodegenerative disorders (Cyr et al. 2000, Dhandapani \& Brann 2002, Littleton-Kearney et al. 2002, Kimelberg et al. 2003, Murphy et al. 2003, Brinton 2004, DonCarlos et al. 2007, Prokai \& Simpkins 2007), since they may have oestrogenic neuroprotective actions in the brain and absence of oestrogenic actions, or even anti-oestrogenic effects, in other tissues, avoiding the peripheral risks associated with oestrogen therapy. A previous study has shown that two SERMs of clinical use in humans, tamoxifen and raloxifene, are able to reduce microglia activation in vitro (Suuronen et al. 2005). In this study, we have assessed the anti-inflammatory effects of $17 \beta$ oestradiol, tamoxifen and raloxifene, in an in vivo model of microglia activation induced by the peripheral administration of the bacterial endotoxin lipopolysaccharide (LPS). Our findings indicate that $17 \beta$-oestradiol, tamoxifen and raloxifene exert anti-inflammatory actions on central nervous system microglia in response to peripheral inflammation and suggest that part of these effects may be exerted directly on microglial cells expressing ER $\alpha$.

\section{Materials and Methods}

\section{Animals and experimental treatments}

Wistar albino male and female rats from the animal colony of Complutense University were kept in a 12:12 h light/dark schedule and received food and water ad libitum. Animals were handled in accordance with the guidelines presented in the UFAW Handbook on the Care and Management of Laboratory Animals (Poole 1999) and following the European Union guidelines (Council Directive 86/609/EEC). Experimental procedures were approved by our institutional animal use and care committee. Special care was taken to minimize suffering and to reduce the number of animals used to the minimum required for statistical accuracy. Females were bilaterally ovariectomized under halothane anaesthesia (Fluothane, AstraZeneca Farmacéutica, Madrid, Spain) to eliminate the influence of cycling changes in ovarian secretions on microglia.

Three-month-old gonadally intact male rats and ovariectomized females ( 1 week or 1 month after ovariectomy), received a first i.p. injection of an oestrogenic compound (see below) and $1 \mathrm{~h}$ later a first i.p. injection of $1 \mathrm{mg} / \mathrm{kg}$ b.w. LPS from Escherichia coli 055:B5 (L2880, Sigma-Aldrich) dissolved in PBS. After 3 days, the animals received a second i.p. injection of the oestrogenic compound and $1 \mathrm{~h}$ later a second i.p. injection of LPS $(1.33 \mathrm{mg} / \mathrm{kg}$ b.w). The pattern and doses of administration of LPS were based on a previous study ( $\mathrm{Ng} \&$ Ling 1997). The control rats received injections of vehicles. Some animals were injected with oestrogenic compounds and the vehicle for LPS and some animals received injections of LPS and the vehicle for oestrogenic compounds. The oestrogenic compounds tested were: 17 $\beta$-oestradiol (E2758, Sigma; 50, 250, 500 and $700 \mu \mathrm{g} / \mathrm{kg}$ b.w.), tamoxifen (T5648, Sigma; 0.5, 1 and $2 \mathrm{mg} / \mathrm{kg}$ b.w.) and raloxifene (R1402, Sigma; 0.5, 1 and $2 \mathrm{mg} / \mathrm{kg} \mathrm{b.w).} \mathrm{The}$ oestrogenic compounds were dissolved in $40 \mu \mathrm{l} / \mathrm{mg}$ dimethylsulphoxide (Sigma) in $0.9 \% \mathrm{NaCl}(\mathrm{pH} 7 \cdot 4)$ and were injected at doses that in previous studies resulted in neuroprotective effects (Picazo et al. 2003, Ciriza et al. 2004).

\section{Tissue fixation and immunohistochemistry}

Four days after the second injection of LPS, animals were deeply anaesthetized with pentobarbital $(50 \mathrm{mg} / \mathrm{kg}$, Normon Veterinary Division, Madrid, Spain) and perfused through the left cardiac ventricle, first with $50 \mathrm{ml}$ saline solution $(0 \cdot 9 \%$ $\mathrm{NaCl})$ and then with $250 \mathrm{ml}$ fixative solution $(4 \%$ paraformaldehyde in $0 \cdot 1 \mathrm{M}$ phosphate buffer, $\mathrm{pH} 7 \cdot 4)$. Brains were removed and immersed for $4-6 \mathrm{~h}$ at $4{ }^{\circ} \mathrm{C}$ in the same fixative solution and then rinsed with phosphate buffer. Sagittal sections of the cerebellum, $50 \mu \mathrm{m}$ thick, were obtained using a vibratome (VT 1000S, Leica Microsystems, Wetzlar, Germany).

Immunohistochemistry was carried out in free-floating sections under moderate shaking. The endogenous peroxidase activity was quenched for $10 \mathrm{~min}$ at room temperature in a solution of $3 \%$ hydrogen peroxide in 30\% methanol. After several washes in $0 \cdot 1 \mathrm{M}$ phosphate buffer $(\mathrm{pH} 7 \cdot 4)$, containing $0 \cdot 3 \%$ BSA, $0 \cdot 3 \%$ Triton $\mathrm{X}-100$ and $0 \cdot 9 \% \mathrm{NaCl}$ (washing buffer), sections were incubated overnight at $4{ }^{\circ} \mathrm{C}$ with one of the following primary antibodies: a mouse monoclonal antibody for major histocompatability complex-II (MHC-II; MRC-OX6, MCA46G, Serotec, Bicester, UK; diluted 1:300); a mouse monoclonal antibody for OX42 (MCA275G, Serotec; diluted 1:300); a mouse anti-rat lysosomal enzyme (anti CD68, ED1, Serotec; diluted 1:1000); a rabbit polyclonal antibody for ER $\alpha$ (MC20, sc 542, raised against an epitope mapping at the C-terminus of ER $\alpha$ of mouse origin, Santa Cruz Biotechnology, Madrid, Spain; diluted 1:300) or a rabbit polyclonal antibody for ER $\beta$ (51-7900, Zymed, Barcelona, Spain; diluted 1:500). Primary antibodies were diluted in washing buffer containing 3\% normal goat serum. To amplify the immunoreactive signal of $E R \alpha$ and $E R \beta$ antibodies, the tyramide signal amplification kit (TSA Biotin System NEL700; NEN Life Science Products) was used in some incubations according to the manufacturer's instructions. After incubation with the primary antibody, sections were then rinsed in buffer and incubated for $2 \mathrm{~h}$ at room temperature with biotinylated goat anti-mouse immunoglobulin G (31800 Pierce, Rockford, IL, USA; diluted 1:250 in washing buffer) or biotinylated goat anti-rabbit immunoglobulin G (31820 Pierce; diluted 1:250 in washing buffer). After several washes in buffer, sections were incubated for $90 \mathrm{~min}$ at room temperature with avidin-biotinperoxidase complex (ImmunoPure ABC peroxidase staining 
kit, Pierce, Rockford, IL, USA; diluted 1:250). The reaction product was revealed by incubating the sections with $2 \mu \mathrm{g} / \mathrm{ml}$ 3,3'-diaminobenzidine (Sigma-Aldrich) and 0.01\% hydrogen peroxide in $0 \cdot 1 \mathrm{M}$ phosphate buffer. Then, sections were dehydrated, mounted on gelatinized slides and observed in a Leica DMRBE microscope.

The possible expression of ERs by microglia was assessed by immunofluorescence using a mouse monoclonal antibody for OX42 (MCA275G, Serotec; diluted 1:300), which recognizes both resting and activated microglia, in combination with one of the following antibodies: a rabbit polyclonal antibody for ER $\alpha$ (MC20, sc 542, Santa Cruz Biotechnology; diluted 1:300); a rabbit polyclonal antibody for ER $\beta$ (51-7900, Zymed; diluted $1: 250)$ or a primary chicken polyclonal antibody for $\operatorname{ER} \beta$ (14021 Abcam, Cambridge, UK; diluted 1:200). The secondary antibodies used were the following: red Alexa-conjugated goat anti-mouse antibody (A-11020, Molecular Probes, Madrid, Spain; diluted 1:1000), green Alexa-conjugated goat anti-rabbit antibody (A-11008, Molecular Probes; diluted 1:1000) and green Alexa-conjugated goat anti-chicken antibody (703-096155, Jackson ImmunoResearch Laboratories, Inc., Madrid, Spain). After several washes in buffer, sections were mounted on histological slides, air-dried overnight at room temperature and cover slipped with an anti-fading water-based medium. The sections were observed using a Leica TCS4D confocal scanner installed in a Leitz DM1RB microscope.

\section{Morphometric analysis}

Number of MHC-II and OX42 immunoreactive cells Preliminary studies showed abundant MHC-II and OX42 immunoreactive cells in the brain white matter tracts and regions of the animals treated with LPS. MHC-II and OX42 immunoreactive cells were highly abundant in the cerebellar white matter, both in the central white matter and in the molecular layer of the cerebellar cortex. The cerebellum was therefore selected for the morphometrical analysis of microglia.

The number of MHC-II and OX42 immunoreactive cells was assessed in the central white matter of the cerebellum in a region dorsal and anterior to the lateral cerebellar nucleus, located between the lobes $2-5$ and at a lateral distance of $\sim 2.4-2.9 \mathrm{~mm}$ from the midline, according to the stereotaxic atlas of the rat brain by Paxinos \& Watson (1986). The number of immunoreactive cells was estimated by the optical disector method (Howard \& Reed 1998) using total section thickness for disector height (Hatton \& von Bartheld 1999) and a counting frame of $220 \times 220 \mu \mathrm{m}$. A total of 60 counting frames were assessed per animal. Section thickness was measured using a digital length gauge device (HeidenhainMetro MT 12/ND221; Traunreut, Germany) attached to the stage of a Leitz microscope. Cell nuclei from immunoreactive cells that came into focus while focusing down through the dissector height were counted. All counts were performed on coded sections. The volume of the central white matter of the cerebellum was estimated according to the Cavalieri's principle using the point-counting method of Weibel (1979). Since no significant differences in this parameter were observed among the different experimental groups, the changes in the number of immunoreactive cells per unit volume with the optical disector method are assumed to reflect changes in the immunoreactive cell content.

Colocalization of ER $\alpha$ and OX42 For each animal, the percentage of OX42 immunoreactive cells showing ER $\alpha$ immunoreactivity in the central white matter of the cerebellum was estimated on microphotographs covering a total area of $0 \cdot 1 \mathrm{~mm}^{2}$. Sections immunostained for both $\mathrm{ER} \alpha$ and OX42 (red and green channels respectively) were photographed at $40 \times$ magnification in a Leica DMI 6000B microscope. Points of colocalization of red and green channels were identified on RGB images with the aid of the colocalization plugin of the Image J software (developed at the USA National Institutes of Health and available on the Internet at http://rsb.info.nih.gov/ij/). The points of colocalization identified by the Image J software were confirmed by visual inspection of the images. Then, the number of OX42 immunoreactive perikarya showing points of ER $\alpha$ immunoreactivity and the total number of OX42 immunoreactive perikarya were counted in each image to estimate the percentage of cell perikarya that colocalized OX 42 and ER $\alpha$.

\section{Statistical analysis}

The $n$ used for statistical analysis was the number of animals indicated in the figure legends. Four animals from each experimental group were evaluated for immunohistochemical colocalization of $\operatorname{ER} \alpha$ and OX42. Since the F-test did not reveal significant differences between variances, data were analysed with ANOVA followed by the Tukey test, with $P<0 \cdot 05$ considered to be significant.

\section{Results}

\section{Effects of LPS on glial cell markers}

Few MHC-II immunoreactive cells were detected in the cerebellum of control rats and obvious qualitative differences in the amount and morphology of immunoreactive cells were observed between the different experimental groups (Figs 1, 3 and 5). MHC-II immunoreactive cells were much more abundant (Figs 1, 3 and 5) and showed larger somas, and retracted and thicker processes (compare inserts in Figs 1A, E and $3 \mathrm{~A}, \mathrm{E})$ in the animals injected with LPS than in control animals injected with vehicles. Similar qualitative differences to those observed with the MHC-II antibody were also detected in sections immunostained with the ED1 antibody, a marker of phagocytic microglia (not shown). The number of MHC-II immunoreactive cells, estimated with the optical dissector method, was significantly increased after LPS administration in both male and female animals (Figs 2, 4 and 6). By contrast, LPS treatment did not affect the total 

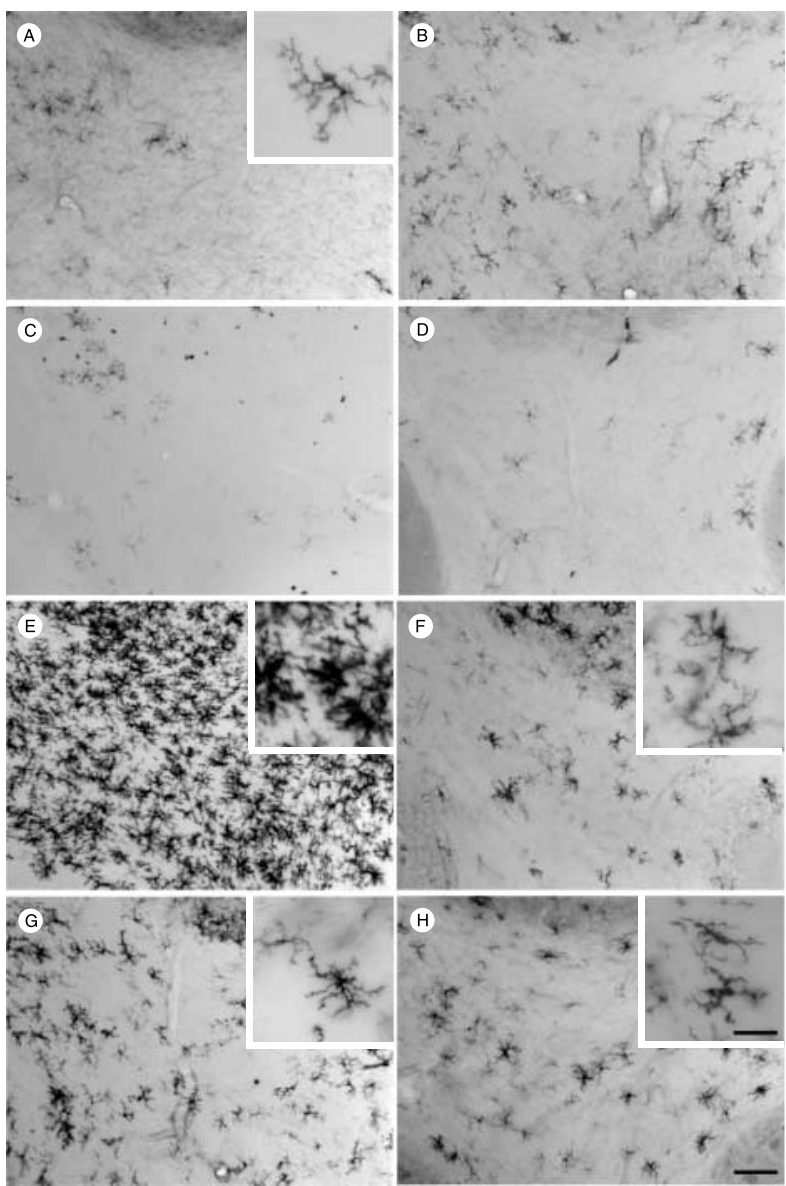

Figure 1 Representative images of the central white matter of the cerebellum of male rats showing immunoreactivity for MHC-II after the following treatments: (A) vehicles for oestrogenic compounds (DMSO) and LPS (phosphate buffer); (B) 17ß-oestradiol, $250 \mu \mathrm{g} / \mathrm{kg}$ b.w.; (C) tamoxifen, $1 \mathrm{mg} / \mathrm{kg}$ b.w.; (D) raloxifene, $1 \mathrm{mg} / \mathrm{kg}$ b.w.; (E) LPS; (F) $17 \beta$-oestradiol, $250 \mu \mathrm{g} / \mathrm{kg}$ b.w. and LPS; (G) tamoxifen, $1 \mathrm{mg} / \mathrm{kg}$ and LPS; and $(\mathrm{H})$ raloxifene, $1 \mathrm{mg} / \mathrm{kg}$ and LPS. Inserts show details of the morphology of MHC-II immunoreactive cells at high magnification. Scale bar, $100 \mu \mathrm{m}$. In the inserts, the scale bar represents $25 \mu \mathrm{m}$.

number of microglial cells, labelled with the pan-microglia marker OX42 (males: controls, 6906 $\pm 413, n=10$; LPS, $8571 \pm 272, n=19$; females: controls, $7258 \pm 414, n=9$; LPS, $8116 \pm 222, n=19$. Data are cells $\left./ \mathrm{mm}^{3}\right)$. Furthermore, the number of OX42 immunoreactive cells was not affected by the experimental treatments with oestrogenic compounds, either in animals treated with LPS or vehicle (not shown).

\section{Effects of oestrogenic compounds on MHC-II immunoreactive} microglia in male rats

Administration of $17 \beta$-oestradiol to male rats resulted in a dosedependent decrease in the number of MHC-II immunoreactive cells (Figs 1 and 2). Animals injected with LPS and treated with oestradiol at the doses of 50 and $250 \mu \mathrm{g} / \mathrm{kg}$ b.w. showed a

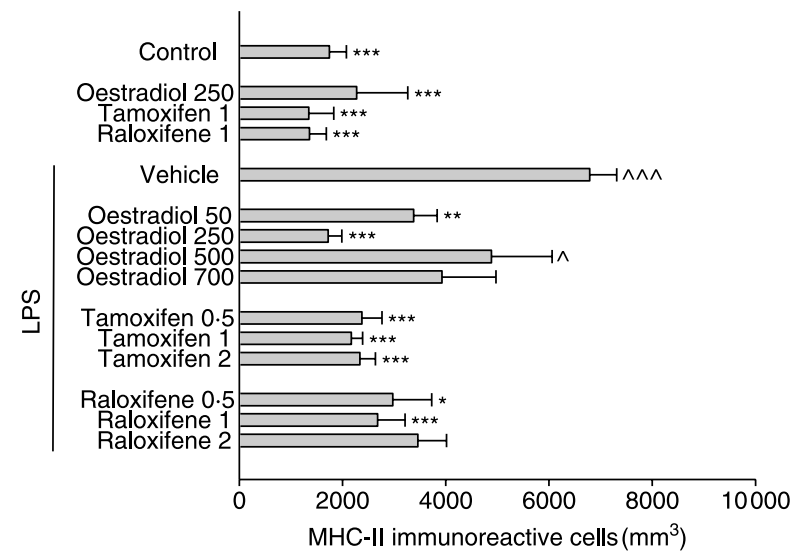

Figure 2 Number of MHC-II immunoreactive cell $\mathrm{s} / \mathrm{mm}^{3}$ in the central white matter of the cerebellum of male rats after the following treatments: vehicles for oestrogenic compounds and LPS (Control, $n=10$ ); oestradiol, $250 \mu \mathrm{g} / \mathrm{kg}$ b.w. (Oestradiol 250, $n=4$ ); tamoxifen, $1 \mathrm{mg} / \mathrm{kg}$. b.w. (Tamoxifen 1, $n=4$ ); raloxifene, $1 \mathrm{mg} / \mathrm{kg}$ b.w. (Raloxifene 1, $n=4$ ); LPS (LPS and Vehicle, $n=16$ ); LPS and oestradiol, $50 \mu \mathrm{g} / \mathrm{kg}$ b.w. (LPS and Oestradiol 50, $n=6$ ); LPS and oestradiol, $250 \mu \mathrm{g} / \mathrm{kg}$ b.w. (LPS and Oestradiol 250, $n=5$ ); LPS and oestradiol, $500 \mu \mathrm{g} / \mathrm{kg}$ b.w. (LPS and Oestradiol 500, $n=8$ ); LPS and oestradiol, $700 \mu \mathrm{g} / \mathrm{kg}$ b.w. (LPS and Oestradiol 700, $n=5$ ); LPS and tamoxifen, $0.5 \mathrm{mg} / \mathrm{kg}$ (LPS and Tamoxifen 0.5, $n=6$ ); LPS and tamoxifen, $1 \mathrm{mg} / \mathrm{kg}$ (LPS and Tamoxifen 1, $n=6$ ); LPS and tamoxifen, $2 \mathrm{mg} / \mathrm{kg}$ (LPS and Tamoxifen 2, $n=6$ ); LPS and raloxifene, $0.5 \mathrm{mg} / \mathrm{kg}$ (LPS and Raloxifene $0 \cdot 5, n=4$ ); LPS and raloxifene, $1 \mathrm{mg} / \mathrm{kg}$ (LPS and Raloxifene 1, $n=8$ ); LPS and raloxifene, $2 \mathrm{mg} / \mathrm{kg}$ (LPS and Raloxifene $2, n=4)$. Data are mean \pm s.E.M. Significant differences versus LPS values: ${ }^{*} P<0 \cdot 05 ;{ }^{* *} P<0 \cdot 01 ;{ }^{* * *} P<0 \cdot 001$. Significant differences versus control values: $\wedge P<0 \cdot 05 ; \wedge \wedge \wedge P<0 \cdot 001$.

decrease in the number of MHC-II cells to values that were significantly lower than those of animals injected with LPS alone and were not significantly different from control values. In addition, MHC-II immunoreactive cells in the animals injected with oestradiol at the doses of 50 and $250 \mu \mathrm{g} / \mathrm{kg} \mathrm{b.w.} \mathrm{and} \mathrm{LPS}$ showed longer and thinner cellular processes and smaller cell somas than in the animals injected with LPS alone (compare inserts in Fig. 1E and F). Higher doses of oestradiol were unable to significantly reduce the number of MHC-II immunoreactive cells in LPS-injected animals. Oestradiol, tested at the dose of $250 \mu \mathrm{g} / \mathrm{kg}$ b.w., did not significantly affect MHC-II immunoreactivity in animals not treated with LPS (Figs 1 and 2).

In contrast to the dose-dependent effect of oestradiol, all the doses of tamoxifen tested in LPS-injected animals (ranging from 0.5 to $2 \mathrm{mg} / \mathrm{kg}$ ) were able to significantly reduce the number of MHC-II immunoreactive cells when compared with the values of animals injected with LPS alone (Figs 1 and 2). MHC-II immunoreactive cells showed longer and thinner cellular processes and smaller cell somas in the animals injected with tamoxifen and LPS when compared with animals injected with LPS alone (compare inserts in Fig. 1E and G). Raloxifene was also able to significantly reduce the reactive morphology of MHC-II immunoreactive cell (compare inserts in Fig. 1E and $\mathrm{H})$ and their number, in LPS-injected animals in comparison with the animals injected with LPS alone, but only at the doses of 
0.5 and $1 \mathrm{mg} / \mathrm{kg}$ (Figs 1 and 2). Tamoxifen and raloxifene per se (tested at $1 \mathrm{mg} / \mathrm{kg}$ b.w.), in absence of LPS, did not affect the number of MHC-II immunoreactive cells (Figs 1 and 2).

Effects of oestrogenic compounds on MHC-II immunoreactive microglia in female rats when the treatments were initiated 1 week after ovariectomy

Having established that oestrogenic compounds were able to reduce the effect of LPS on the number of MHC-II immunoreactive cells in the cerebellum of male rats, in a second series of experiments we assessed whether these compounds had similar effects in females. Female rats were ovariectomized to eliminate the fluctuation of ovarian hormones during the oestrous cycle. In a first experiment, the treatment with LPS and oestrogenic compounds were initiated 1 week after ovariectomy. As in males, oestradiol administration to LPS-injected females decreased, in a dosedependent manner, the number of MHC-II to control values (Figs 3 and 4). Oestradiol also reduced the reactive morphology of microglia (compare inserts in Fig. 3E and F). However, in contrast to males, the lower dose of oestradiol tested $(50 \mu \mathrm{g} / \mathrm{kg}$ b.w.) did not significantly reduce the number of MHC-II cells in LPS-injected animals. By contrast, both the doses of 250 and $500 \mu \mathrm{g} / \mathrm{kg}$ b.w. resulted in a significant decrease in the number of MHC-II immunoreactive cells (Figs 3 and 4). Oestradiol, tested at the dose of $250 \mu \mathrm{g} / \mathrm{kg}$ b.w., did not significantly affect MHC-II immunoreactivity in animals that were not treated with LPS (Figs 3 and 4).

As observed in male rats, all the tested doses of tamoxifen resulted in a reduction in the reactive morphology of microglia (see inserts in Fig. 3E and G) and decreased the number of MHC-II in LPS-injected animals to values that were not significantly different from those of control animals injected with vehicles (Figs 3 and 4). The maximal effect was observed with the dose of $1 \mathrm{mg} / \mathrm{kg}$. Raloxifene, at doses of 0.5 and $1 \mathrm{mg} / \mathrm{kg}$ b.w. reduced the number of MHC-II immunoreactive cells to control levels and decreased the reactive morphology of microglia (compare inserts in Fig. 3E and $\mathrm{H})$. However, at a higher dose $(2 \mathrm{mg} / \mathrm{kg}$ b.w.), raloxifene did not significantly modify the number of MHC-II immunoreactive cells in comparison with the animals injected with LPS alone (Fig. 4). The administration of tamoxifen $(1 \mathrm{mg} / \mathrm{kg} \quad$ b.w. $)$ or raloxifene $(1 \mathrm{mg} / \mathrm{kg}$ b.w. $)$ to ovariectomized females that were not treated with LPS did not significantly affect the number of MHC-II immunoreactive cells in comparison with the control values (Figs 3 and 4). However, raloxifene had a moderate inflammatory effect not observed in males, since MHC-II immunoreactive cells in animals injected with raloxifene, in absence of LPS, showed morphological characteristics of reactive microglia, with thicker cell bodies and cellular processes (compare inserts in Fig. $3 \mathrm{~A}$ and D). In addition, the number of MHC-II immunoreactive cells after the administration of raloxifene, in absence of LPS, was not significantly different to the values of the LPS group (Fig. 4).
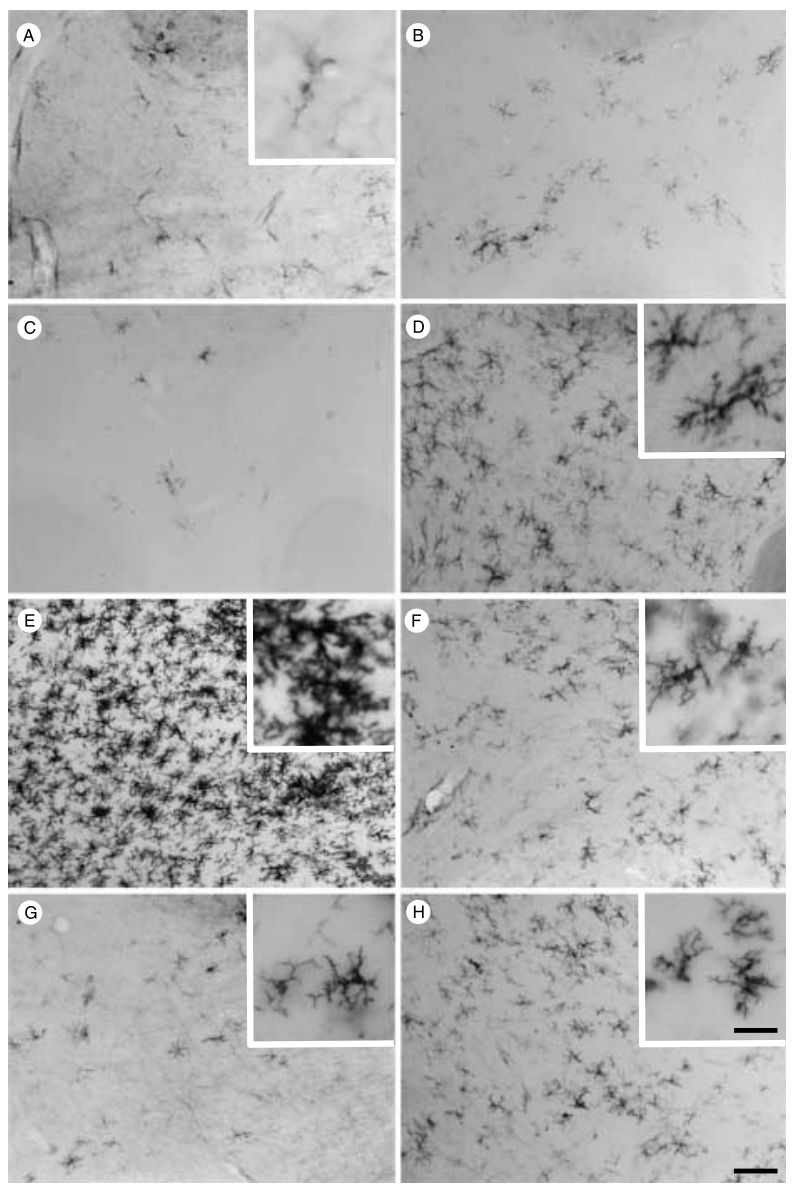

Figure 3 MHC-II immunoreactivity in the central white matter of the cerebellum of female rats in which treatments with oestrogenic compounds and LPS were initiated 1 week after ovariectomy. The figures show representative images after the following treatments: (A) vehicles; (B) $17 \beta$-oestradiol, $250 \mu \mathrm{g} / \mathrm{kg}$ b.w.; (C) tamoxifen, $1 \mathrm{mg} / \mathrm{kg}$ b.w.; (D) raloxifene, $1 \mathrm{mg} / \mathrm{kg}$ b.w.; (E) LPS; (F) $17 \beta$ oestradiol, $250 \mu \mathrm{g} / \mathrm{kg}$ b.w. and LPS; (G) tamoxifen, $1 \mathrm{mg} / \mathrm{kg}$ and LPS; and $(\mathrm{H})$ raloxifene, $1 \mathrm{mg} / \mathrm{kg}$ and LPS. Inserts show details of the morphology of MHC-II immunoreactive cells at high magnification. Scale bar, $100 \mu \mathrm{m}$. In the inserts, the scale bar represents $25 \mu \mathrm{m}$.

Effects of oestrogenic compounds on MHC-II immunoreactive microglia in female rats when the treatments were initiated 1 month after ovariectomy

In a second group of female rats, the treatments with LPS and oestrogenic compounds were initiated 1 month after ovariectomy to determine whether differences in previous duration of ovarian hormone deprivation may affect the response of MHC-II cells (Figs 5 and 6). In animals injected with LPS 1 month after ovariectomy, both oestradiol $(250 \mu \mathrm{g} / \mathrm{kg}$ b.w.) and tamoxifen $(0.5$ and $1 \mathrm{mg} / \mathrm{kg}$ b.w.) decreased the number of MHC-II immunoreactive cells to values significantly lower than in the animals injected with LPS alone (Figs 5 and 6). As observed in female rats when the treatments were initiated 1 


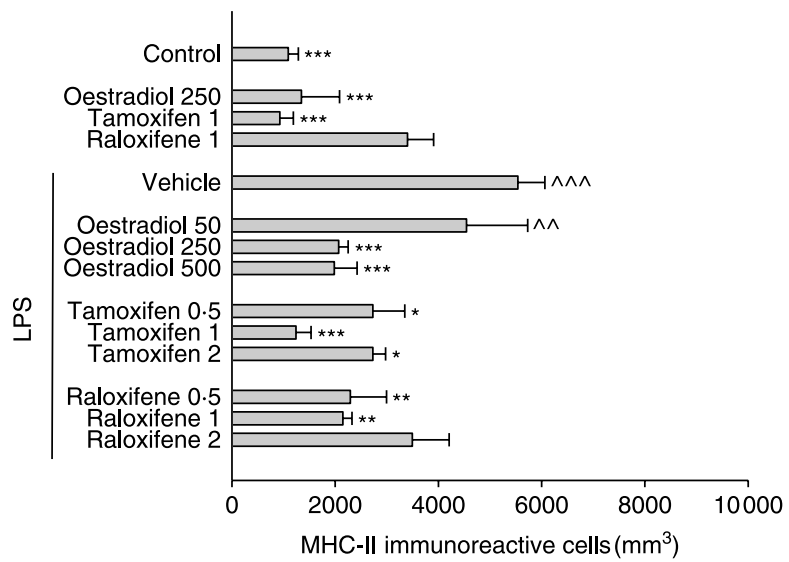

Figure 4 Number of MHC-II immunoreactive cells $/ \mathrm{mm}^{3}$ in the central white matter of the cerebellum of female rats in which treatments with oestrogenic compounds and LPS were initiated 1 week after ovariectomy. Treatments and the number of animals studied for each treatment are as follows: vehicles (Control, $n=9$ ); oestradiol, $250 \mu \mathrm{g} / \mathrm{kg}$ b.w. (Oestradiol 250, $n=4)$; tamoxifen, $1 \mathrm{mg} / \mathrm{kg}$. b.w. (Tamoxifen 1, $n=4$ ); raloxifene, $1 \mathrm{mg} / \mathrm{kg}$ b.w. (Raloxifene $1, n=4$ ); LPS (LPS and Vehicle, $n=16$ ); LPS and oestradiol, $50 \mu \mathrm{g} / \mathrm{kg}$ b.w. (LPS and Oestradiol 50, $n=4$ ); LPS and oestradiol, $250 \mu \mathrm{g} / \mathrm{kg}$ b.w. (LPS and Oestradiol 250, $n=5$ ); LPS and oestradiol, $500 \mu \mathrm{g} / \mathrm{kg}$ b.w. (LPS and Oestradiol 500, $n=5$ ); LPS and tamoxifen, $0.5 \mathrm{mg} / \mathrm{kg}$ (LPS and Tamoxifen 0·5, $n=5$ ); LPS and tamoxifen, $1 \mathrm{mg} / \mathrm{kg}$ (LPS and Tamoxifen 1, $n=4$ ); LPS and tamoxifen, $2 \mathrm{mg} / \mathrm{kg}$ (LPS and Tamoxifen $2, n=5$ ); LPS and raloxifene, $0.5 \mathrm{mg} / \mathrm{kg}$ (LPS and Raloxifene 0.5 , $n=4) ;$ LPS and raloxifene, $1 \mathrm{mg} / \mathrm{kg}$ (LPS and Raloxifene 1, $n=4) ;$ LPS and raloxifene, $2 \mathrm{mg} / \mathrm{kg}$ (LPS and Raloxifene 2, $n=4$ ). Data are mean \pm S.E.M. Significant differences versus LPS values: $* P<0 \cdot 05$; $* * P<0 \cdot 01 ; * * * P<0 \cdot 001$. Significant differences versus control values: $\wedge \wedge P<0 \cdot 01 ; \wedge \wedge \wedge P<0 \cdot 001$.

week after ovariectomy, the maximal effect of tamoxifen was observed with a dose of $1 \mathrm{mg} / \mathrm{kg}$ b.w. Therefore, the response of MHC-II immunoreactive cells to oestradiol and tamoxifen was similar after 1 month and 1 week of ovariectomy. Raloxifene, at the dose of $0.5 \mathrm{mg} / \mathrm{kg}$ b.w., also resulted in a significant reduction in the number of $\mathrm{MHC}-\mathrm{II}$ immunoreactive cells, as observed in female rats when the treatments were initiated 1 week after ovariectomy (Figs 5 and 6). However, the antiinflammatory effect of raloxifene was loss at the dose of $1 \mathrm{mg} / \mathrm{kg}$ b.w. in female animals injected with LPS 1 month after ovariectomy. The number of MHC-II cells in animals injected with LPS and raloxifene at the dose of $1 \mathrm{mg} / \mathrm{kg}$ was significantly increased in comparison with the control values and was not significantly different from the values of animals injected with LPS alone (Fig. 6). Therefore, the anti-inflammatory effect of raloxifene was partially impaired after 1 month of deprivation of ovarian hormones.

\section{Expression of ERs in microglia}

The possible expression of ERs in microglia was explored by immunohistochemistry. As expected from previous reports (Shughrue et al. 1997, Price \& Handa 2000), ER $\beta$ immunoreactivity was observed in the Purkinje cells (Fig. 7). However,

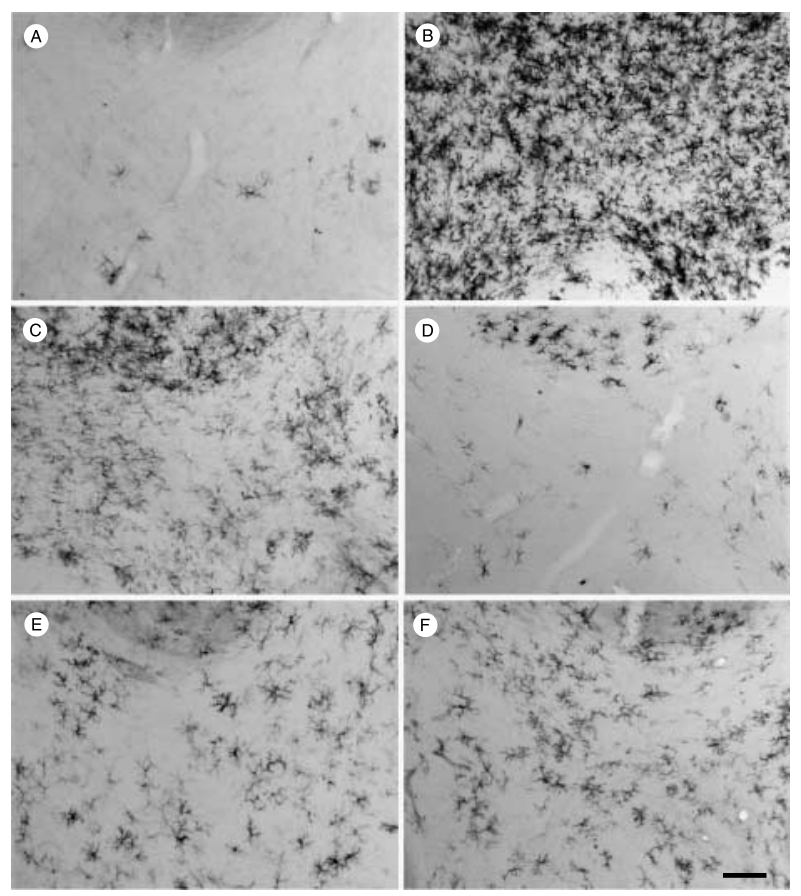

Figure $5 \mathrm{MHC}-\mathrm{II}$ immunoreactivity in the central white matter of the cerebellum of female rats in which treatments with oestrogenic compounds and LPS were initiated 1 month after ovariectomy. The figures show representative images after the following treatments: (A) vehicles; (B) LPS; (C) 17 $\beta$-oestradiol, $250 \mu \mathrm{g} / \mathrm{kg}$ b.w. and LPS; (D) tamoxifen, $1 \mathrm{mg} / \mathrm{kg}$ and LPS; (E) raloxifene, $0.5 \mathrm{mg} / \mathrm{kg}$ and LPS; (F) raloxifene, $1 \mathrm{mg} / \mathrm{kg}$ and LPS. Scale bar, $100 \mu \mathrm{m}$.

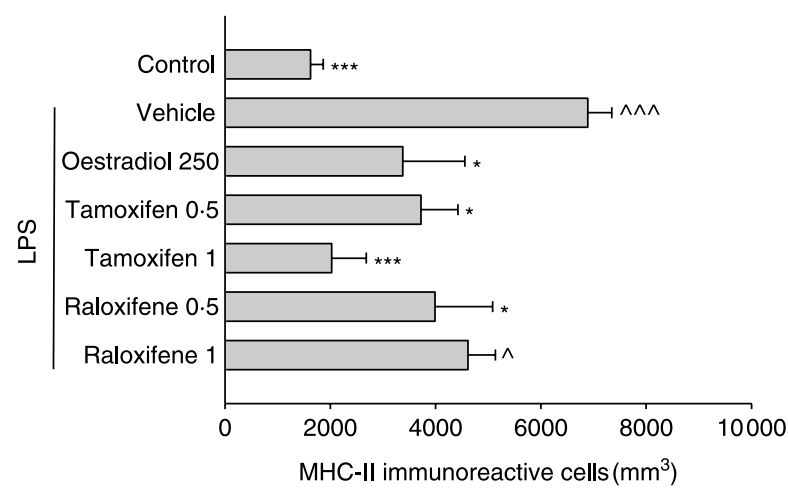

Figure 6 Number of MHC-II immunoreactive cells $/ \mathrm{mm}^{3}$ in the central white matter of the cerebellum of female rats in which treatments with oestrogenic compounds and LPS were initiated 1 month after ovariectomy. Treatments and the number of animals studied for each treatment are as follows: vehicles (Control, $n=10$ ); LPS (LPS and Vehicle, $n=9$ ); LPS and oestradiol, $250 \mu \mathrm{g} / \mathrm{kg}$ b.w. (LPS and Oestradiol 250, $n=3$ ); LPS and tamoxifen, $0.5 \mathrm{mg} / \mathrm{kg}$ and LPS (Tamoxifen $0 \cdot 5, n=5$ ); LPS and tamoxifen, $1 \mathrm{mg} / \mathrm{kg}$ (LPS and Tamoxifen 1, $n=4$ ); LPS and raloxifene, $0.5 \mathrm{mg} / \mathrm{kg}$ (LPS and Raloxifene $0 \cdot 5, n=4$ ); LPS and raloxifene, $1 \mathrm{mg} / \mathrm{kg}$ (LPS and Raloxifene 1, $n=4)$. Data are mean \pm S.E.M. Significant differences versus LPS values: ${ }^{*} P<0 \cdot 05 ; * * * P<0 \cdot 001$. Significant differences versus control values: $\wedge P<0 \cdot 05 ; \wedge \wedge \wedge P<0 \cdot 001$. 


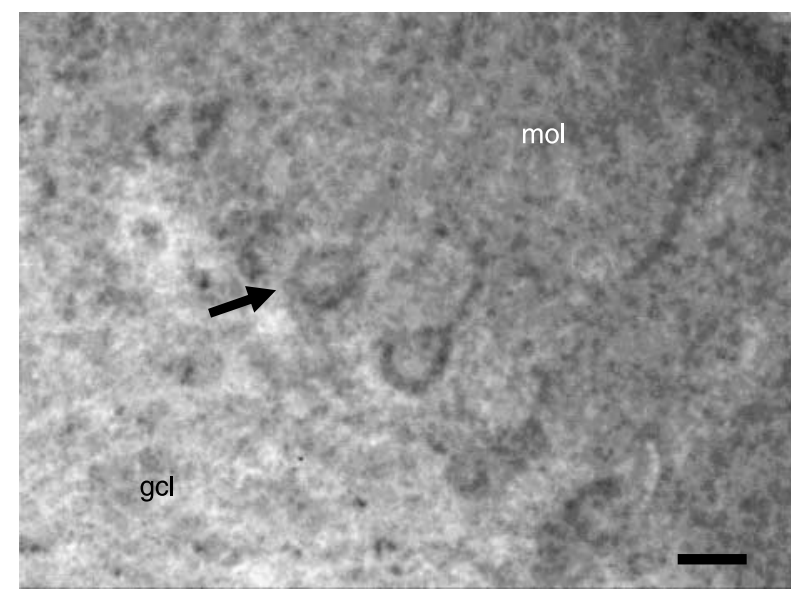

Figure 7 Immunostaining in Purkinje cells (arrow) using the rabbit polyclonal antibody for ER $\beta$. mol, molecular layer; gcl, granule cell layer. Scale bar, $25 \mu \mathrm{m}$.

we were unable to detect any evidence of colocalization of ER $\beta$ immunoreactivity with the microglial marker OX42, neither in control animals injected with vehicles nor in animals injected with oestrogenic compounds, LPS or the combination of LPS and oestrogenic compounds. Identical results were obtained with the two ER $\beta$ antibodies tested.

By contrast, ER $\alpha$ immunoreactivity was colocalized with OX42 (Fig. 8). Under basal conditions, the pattern of ER $\alpha$ immunoreactivity was diffused and in a first examination, in control animals, we considered the staining as background (Fig. 8D). However, in animals treated with LPS 1 week after ovariectomy, ER $\alpha$ immunoreactivity clearly delineated cell somas (Fig. $8 \mathrm{H}$ ) and punctiform ER $\alpha$ immunostaining in the cell perikarya and processes of OX42 immunoreactive cells was evident (Fig. 8G). The punctiform staining was not observed when the incubation with the primary ER $\alpha$ antibody was omitted. As a control of the specificity of the $\mathrm{ER} \alpha$ signal, we used sections from $\mathrm{ER} \alpha \mathrm{KO}$ mice from another study in which microglia activation was induced by a stab wound in the cerebral cortex and the hippocampus. ER $\alpha$ immunoreactivity was not detected in OX42 immunoreactive cells from ER $\alpha \mathrm{KO}$ mice (not shown).

The estimation of the percentage of OX42 immunoreactive perikarya showing ER $\alpha$ immunostaining revealed a significant increase in animals treated with LPS 1 week after ovariectomy ( $67 \pm 5$ vs $88 \pm 3 \%$ in controls and LPSinjected animals respectively; S.D., $P<0 \cdot 01$ ). Treatment with oestradiol $(250 \mu \mathrm{g} / \mathrm{kg})$ also increased the localization of ER $\alpha$ immunoreactive spots in the perikaryon of OX 42 immunoreactive cells and the percentage of colocalization under basal conditions in the absence of LPS $(87 \pm 0 \cdot 5 \%$; s.D., $P<0 \cdot 01$ versus control values). However, oestradiol treatment counteracted the effect of LPS on the percentage of colocalization ( $73 \pm 2 \%$; S.D., $P<0 \cdot 01$ versus LPS values). As observed for oestradiol, tamoxifen treatment $(1 \mathrm{mg} / \mathrm{kg}$ b.w. $)$ increased the percentage of OX42 immunoreactive cells with
ER $\alpha$ immunostaining under basal conditions $(93 \pm 1 \%$; S.D., $P<0.05$ versus control values). However, tamoxifen did not significantly affect the percentage of colocalization in the animals injected with LPS ( $81 \pm 8 \%)$. Raloxifene $(1 \mathrm{mg} / \mathrm{kg}$ b.w.) did not significantly affect the percentage of OX42 immunoreactive cells with ER $\alpha$ immunostaining under basal conditions and did not significantly modify the colocalization in LPS-injected animals (not shown). Different results were obtained when the treatments were initiated 1 month after ovariectomy. Under these conditions, the percentage of cells colocalizing ER $\alpha$ and OX42 was not significantly affected by LPS or by the combination of LPS and oestradiol or LPS and tamoxifen $(50 \pm 3,37 \pm 5,52 \pm 8$, and $46 \pm 6 \%$ in animals treated with vehicle, LPS, oestradiol and LPS, and tamoxifen and LPS respectively). By contrast, the combination of LPS and raloxifene induced a significant decrease in the percentage of cells colocalizing ER $\alpha$ and OX42 when compared with vehicle values $(36 \pm 1 \%$; S.D., $P<0 \cdot 01)$. Furthermore, the basal percentage of OX42 immunoreactive perikarya showing ER $\alpha$ immunostaining was significantly decreased 1 month after ovariectomy $(50 \pm 3 \%)$ when compared with 1 week after ovariectomy $(67 \pm 5 \%$; S.D., $P<0 \cdot 05)$.

\section{Discussion}

Inflammation in the central nervous system is regulated by resident glial cells and infiltrating immune cells (Ladeby et al. 2005, Pekny \& Nilsson 2005). In this study, we have used an animal model of peripheral inflammation elicited by the systemic administration of LPS. The systemic LPS administration has been previously described as a reliable method to induce the activation of microglia in the rat brain (Buttini et al. 1996, Ng \& Ling 1997, Semmler et al. 2005, Qin et al. 2007, Sierra et al. 2007). The microglia respond to inflammatory stimuli, such as LPS, with the retraction and thickening of the cellular processes, swelling of the cell body, production of proinflammatory cytokines and overexpression of myeloid markers such as MHC-II (Ladeby et al. 2005). The expression of MHC-II is considered as a reliable marker of microglia activation. The MHC-II immunoreactivity is practically undetectable in resting microglia, but reactive microglia cells overexpress MHC-II in response to neurotoxins (Cevolani et al. 2001), neural injury (Popovich et al. 1997, Hong et al. 2006) or inflammatory stimuli, such as LPS (Ng \& Ling 1997, Hauss-Wegrzyniak et al. 1998). In agreement with this, we have detected a marked increase in the number of MHC-II immunoreactive cells in the brain after systemic administration of LPS. The MHC-II immunoreactive cells were particularly abundant in white matter tracts and we selected the central white matter of the cerebellum for the study. The morphology of the MHC-II immunoreactive cells, with swelled somas and with retracted and thick processes, was the expected for the activated microglia (Ladeby et al. 2005). As an additional marker for inflammation, some sections from each experimental group were immunostained with an anti-rat lysosomal 

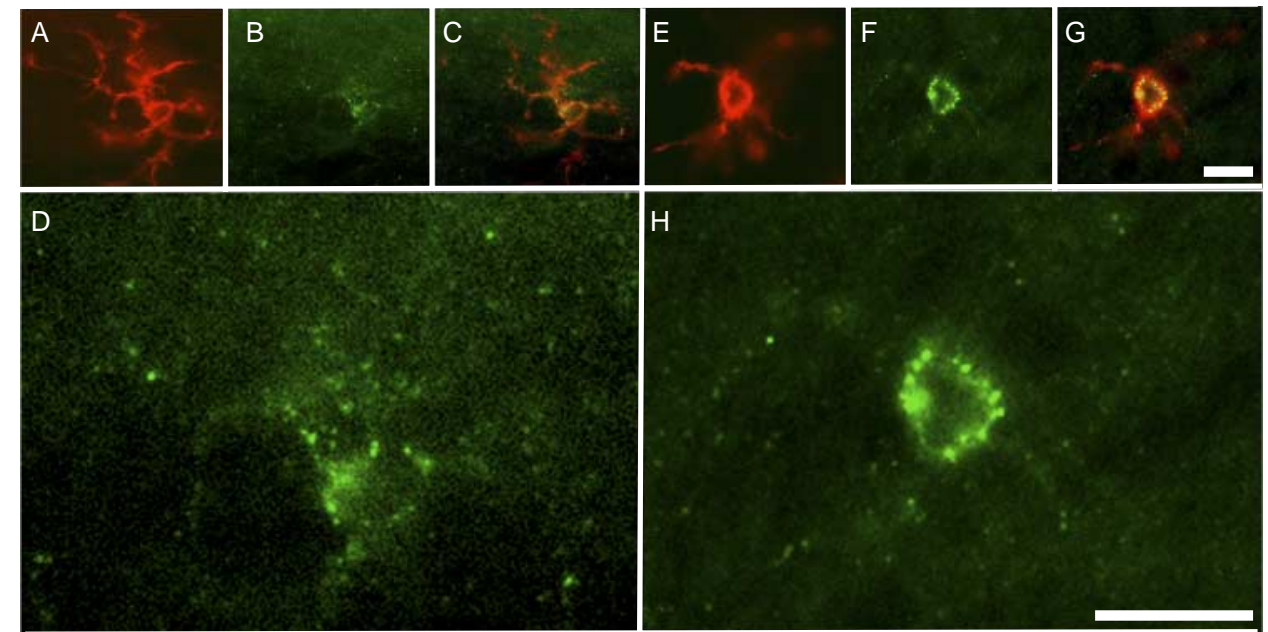

Figure 8 Colocalization of OX42 immunoreactivity (red) and $E R \alpha$ immunoreactivity (green) in the central white matter of the cerebellum of ovariectomized female rats. (A-D) Control animal and $(E-H)$ animal injected with LPS 1 week after ovariectomy. (A and E) Examples of OX42 immunoreactive cells. (B and F) ER $\alpha$ immunoreactivity in the same microscopic fields of ( $A$ and $E$ ) respectively. ( $C$ and $G$ ) Merge of the green and red channels showing points of colocalization (yellow) of OX42 and ER $\alpha$ in the soma and cellular processes of OX42 immunoreactive cells. ( $\mathrm{D}$ and $\mathrm{H}$ ) High magnification of the cells that are shown in ( $\mathrm{B}$ and $\mathrm{F}$ ) respectively. LPS administration enhanced the localization of ER $\alpha$ immunoreactivity in the cell body. Scale bars, $10 \mu \mathrm{m}$. Full colour version of this figure available via http://dx.doi.org/10.1677/JOE-07-0294.

enzyme antibody (anti CD68; ED1), which is a reliable phagocytic marker and detects phagocytic microglia (Graeber et al. 1990, Bauer et al. 1994). Similar qualitative results were obtained with both MHC-II and ED1 antibodies.

Previous studies have shown that microglia activation and gene expression are affected by the ovarian hormone oestradiol. Studies in microglia cultures have shown that oestradiol inhibits the expression of inducible nitric oxide synthase and several other inflammatory mediators in response to LPS and proinflammatory cytokines (Bruce- Keller et al. 2000, 2001, Drew \& Chavis 2000, Vegeto et al. 2001, Baker et al. 2004, Dimayuga et al. 2005). Studies in vivo have also demonstrated that oestradiol reduces microglia reactivity and the expression of cytokines and chemokines induced by an acute intracerebroventricular injection of LPS in female mice (Vegeto et al. 2001, 2003, 2006). Oestradiol is also effective in reducing chronic microglia activation around $\beta$-amyloid plaques in the brain of APP23 female mice, a model of Alzheimer's disease (Vegeto et al. 2006) and the hormone reduces microglia activation after a stab wound injury in the hippocampus (Barreto et al. 2007). In agreement with these previous findings, we have found in this study that oestradiol decreases microglia activation after the systemic administration of LPS. The effect of oestradiol was observed in ovariectomized females and in intact males, indicating that the hormone may also participate in anti-inflammatory effects in the male rat brain.

Our present findings also indicate that two SERMs currently used for therapeutic purposes in humans, tamoxifen and raloxifene, at doses within the range used in the clinical practice (Bernstein et al. 1999, Palacios et al. 2004, Stovall et al. 2007), are able to reduce microglia activation in the central nervous system after systemic administration of LPS in males and females. Previous studies have shown that tamoxifen and raloxifene decrease the LPS-induced inflammatory response in microglial cells in vitro (Suuronen et al. 2005) and that raloxifene decreases the number of microglial cells in the brain of aged animals (Lei et al. 2003). In addition, tamoxifen has been reported to reduce rat brain damage after ischaemia in vivo (Kimelberg et al. 2003, Mehta et al. 2003, Feng et al. 2004, Zhang et al. 2005) and both tamoxifen and raloxifene prevent excitotoxic-induced neuronal loss in the hippocampus of rats injected with kainic acid (Ciriza et al. 2004). In addition, these SERMs exert neuroprotective effects in different in vitro models (Du et al. 2004, Benvenuti et al. 2005, Biewenga et al. 2005). Although in vitro studies indicate that tamoxifen and raloxifene may have direct neuroprotective effects on the neuronal cells (Du et al. 2004, Benvenuti et al. 2005, Biewenga et al. 2005), our findings suggest that both SERMs may also exert in part its neuroprotective effects in vivo by the regulation of microglia activation.

Although the response of microglia to oestradiol and SERMs was, in general, similar between males and females treated 1 week and 1 month after ovariectomy, we have detected some interesting differences. For instance, the doses of oestradiol effective in decreasing microglia reactivity were not the same in males and females. In addition, raloxifene had per se a moderate pro-inflammatory action in females but not in males. These differences suggest that the very different endocrine status of gonadally intact males and ovariectomized females may affect the pro- and anti-inflammatory response to oestrogenic compounds. The differences may also reflect a sexually dimorphic response of microglia to oestrogenic ligands. In addition, although both tamoxifen and raloxifene were able to 
reduce microglia activation, the anti-inflammatory effect of tamoxifen was detected at all the doses tested, while raloxifene lost its anti-inflammatory effects at the highest studied dose ( $2 \mathrm{mg} / \mathrm{kg}$ b.w.) in animals treated 1 week after ovariectomy. Interestingly, a previous study examining the neuroprotective effect of similar doses of these two SERMs in vivo showed that tamoxifen was neuroprotective at all the doses tested, while raloxifene loses neuroprotective potency at the dose of $2 \mathrm{mg} / \mathrm{kg}$ b.w. (Ciriza et al. 2004). Therefore, tamoxifen seems to have a better anti-inflammatory profile in the brain than raloxifene. On the other hand, the moderate pro-inflammatory action of raloxifene in the brain of females that were not treated with LPS suggests that some oestrogenic compounds may have a negative impact in healthy brain, even if they are able to decrease brain inflammation under pathological conditions. This possibility, merits to be further explored in detail, and may be highly relevant for human therapy and for the interpretation of the neurological outcome of randomized clinical trials in which oestrogenic compounds are administered to asymptomatic postmenopausal women.

Our present findings, showing that oestrogenic compounds are able to reduce microglia activation after systemic inflammation, are complementary to previous studies in vivo, in which oestradiol has been shown to reduce microglia activation after local brain inflammation (Vegeto et al. 2001, 2003, 2006). In our study, the activation of microglia was probably secondary to peripheral inflammation since there is a reduced passage of peripheral LPS through the blood-brain barrier (Nadeau \& Rivest 1999). The systemic proinflammatory cytokines, such as tumour necrosis factor- $\alpha$, are critical for the transfer of the peripheral inflammation induced by LPS to the central nervous system (Qin et al. 2007). These pro-inflammatory cytokines cross the bloodbrain barrier and activate microglia and astroglia to produce more inflammatory factors (Laye et al. 1994, Pitossi et al. 1997, Eriksson et al. 2000, Combrinck et al. 2002, Choi et al. 2003, Zuurman et al. 2003, Sierra et al. 2007), which will finally cause chronic inflammation in the central nervous system and progressive neurodegeneration (Perry et al. 2003, Cunningham et al. 2005, Semmler et al. 2005, Qin et al. 2007). Therefore, in our model, oestrogenic compounds may potentially reduce microglia activation and brain damage by decreasing the peripheral release of pro-inflammatory molecules. In addition, oestrogenic compounds may also cross the blood-brain barrier and act directly on the cerebellum to reduce the inflammatory effect of peripheral cytokines. Indeed, oestradiol has been shown to reduce inflammatory activation in primary microglia cultures and in microglia cell lines that express ERs (Bruce-Keller et al. 2000, 2001, Drew \& Chavis 2000, Vegeto et al. 2001, Baker et al. 2004, Dimayuga et al. 2005). Previous studies have detected the expression of ER $\beta$ in microglia in the hippocampus of monkeys after cerebral ischaemia (Takahashi et al. 2004) and $\mathrm{ER} \alpha$ in microglia isolated from the brain of adult mice (Sierra et al. 2008). Our present findings suggest that microglial cells in the rat cerebellum, in vivo, express ER $\alpha$ but apparently not
$\operatorname{ER} \beta$, although it cannot be excluded that $\operatorname{ER} \beta$ is expressed by cerebellar microglia at levels too low to be detected by classical immunohistochemical techniques. The spotted localization of $\mathrm{ER} \alpha$ immunoreactivity in the cellular processes and in the perikaryon of microglial cells agrees with previous findings by electron microscopic immunodetection of ER $\alpha$ in the hippocampus of mice (Sierra et al. 2008) and is compatible with non classical ER-mediated mechanisms of action, activating membrane and/or cytoplasmic signalling (Beyer et al. 2003, Kelly et al. 2005, Marin et al. 2005, Suuronen et al. 2005). In this regard it is of interest that in macrophages, oestradiol exerts an anti-inflammatory effect by a non-classical mechanism of action, which involves the activation of phosphatidylinositol 3-kinase that in turn is mediated by $\operatorname{ER} \alpha$, and not by $\operatorname{ER} \beta$ (Ghisletti et al. 2005). Furthermore, central anti-inflammatory actions of oestradiol after intracerebral injection of LPS are at loss in ER $\alpha \mathrm{KO}$ mice (Vegeto et al. 2003), suggesting that ER $\alpha$ expressed by brain cells is involved in the oestrogenic effect.

Sierra et al. (2008) have recently detected a decrease in the $m R N A$ levels of $E R \alpha$ in microglia isolated from the brain of mice treated with LPS, indicating that ER $\alpha$ expression in microglia is regulated by inflammatory challenge. In agreement with this, we have found that LPS regulates $\mathrm{ER} \propto$ immunoreactivity in rat cerebellar microglia. However, in our study, we have detected an increase in the percentage of microglial cells immunoreactive for ER $\alpha$, while Sierra et al. (2008) detected a decrease in mRNA levels in microglia. Among other possible causes, such as the different time courses of the analysis after exposure to LPS, hours in the case of the study of Sierra et al. (2008) and days in our study, may explain the apparent discrepancy. However, further studies are necessary to determine the precise time course of ER $\alpha$ changes in microglia after immune challenge. Our results also suggest that the duration of hormone deprivation may affect the action of LPS on ER $\alpha$ immunoreactivity and that some oestrogenic compounds, such as $17 \beta$-oestradiol and tamoxifen, may regulate the amount of ER $\alpha$ in the perikarya of microglial cells in animals treated 1 week after ovariectomy. This effect may be mediated by changes in the expression and/or the intracellular localization of $\mathrm{ER} \alpha$ in microglia. Furthermore, $17 \beta$-oestradiol counteracts the effect of LPS on the distribution of $E R \alpha$ immunoreactivity in microglia in animals treated 1 week after ovariectomy. These findings suggest that $\mathrm{ER} \alpha$ is involved in the response of microglia to LPS and oestrogenic compounds. Therefore, at least a part of the anti-inflammatory effects of oestrogenic compounds in the brain may be exerted by a direct effect on microglial cells expressing ER $\alpha$. In addition, oestrogenic compounds may act on ERs expressed in other cerebellar cells such as Purkinje neurons, which are shown in this and previous studies (Shughrue et al. 1997, Price \& Handa 2000), express ER $\beta$. The axons of Purkinje neurons cross the central white matter of the cerebellum, and therefore their functional interaction with microglia in this location is conceivable. Afferent axons 
to the cerebellum from neurons expressing ERs may also transmit indirectly oestrogenic signals to microglia.

Finally, our findings in females showing an impairment of the anti-inflammatory action of raloxifene, at the dose of $1 \mathrm{mg} / \mathrm{kg}$ b.w., 1 month after ovariectomy, in comparison with its anti-inflammatory activity 1 week after ovariectomy, indicate that previous duration of ovarian hormonal deprivation may affect the anti-inflammatory effects of some SERMs. Endocrine induced changes in the expression of ERs or cofactors for ER transcription in the neural cells may be the cause of this difference. Indeed, our findings suggest that the basal expression of ER $\alpha$ in microglia is reduced and its response to LPS is extinct by 1 month after ovariectomy when compared with 1 week after ovariectomy. In addition, raloxifene did not affect the localization of ER $\alpha$ in microglia in animals treated with LPS 1 week after ovariectomy, but decreased the localization of ER $\alpha$ in microglia in animals treated with LPS 1 month after ovariectomy. The modification in the response of raloxifene with the duration of the deprivation of ovarian hormones may have relevance for therapeutic use of this SERM. Interestingly, a recent study has shown that oestrogen treatment given immediately at the time of ovariectomy in rodents attenuates central and peripheral production of pro-inflammatory cytokines after ischaemic stroke. By contrast, oestradiol did not suppress production of pro-inflammatory molecules when it was administered after 10-week postovariectomy (Suzuki et al. 2007). Therefore, the neuroprotective and anti-inflammatory actions of oestradiol and oestrogenic compounds may be affected by the duration of the deprivation of ovarian hormones and this may at least partially explain the differences observed in the outcome of hormonal therapy between peri- and post-menopausal women (Maki 2005, Miller et al. 2005).

In summary, our findings indicate that $17 \beta$-oestradiol and the SERMs tamoxifen and raloxifene reduce microglia activation in male and female rats, after peripheral inflammation induced by LPS administration, by a mechanism that may involve ERs in microglia. While tamoxifen reduced microglia activation at all the doses tested, raloxifene lost antiinflammatory activity at high doses and had moderate proinflammatory effects per se in female brains. Furthermore, in females, previous duration of ovarian hormonal deprivation affects the anti-inflammatory action of raloxifene. These findings indicate that the modulation of the activity of ERs using SERMs represents a potential therapeutic approach to reduce microglia activation and central nervous system damage after systemic inflammation and suggest that previous duration of ovarian hormonal deprivation may affect the activity of some oestrogenic compounds on microglia.

\section{Declaration of Interest}

The authors declare that there is no conflict of interest that would prejudice its impartiality.

\section{Funding}

This study has been supported by Ministerio de Educación y Ciencia, Spain (SAF 2005-00272) and the European Union (EWA project: LSHM-CT-2005-518245).

\section{References}

Baker AE, Brautigam VM \& Watters JJ 2004 Estrogen modulates microglial inflammatory mediator production via interactions with estrogen receptor beta. Endocrinology 145 5021-5032.

Barreto G, Veiga S, Azcoitia I, Garcia-Segura LM \& Garcia-Ovejero D 2007 Testosterone decreases reactive astroglia and reactive microglia after brain injury in male rats: role of its metabolites oestradiol and dihydrotestosterone. European Journal of Neuroscience 25 3039-3046.

Bauer J, Sminia T, Wouterlood FG \& Dijkstra CD 1994 Phagocytic activity of macrophages and microglial cells during the course of acute and chronic relapsing experimental autoimmune encephalomyelitis. Journal of Neuroscience Research 38 365-375.

Belandia B \& Parker MG 2003 Nuclear receptors: a rendez-vous for chromatin remodeling factors. Cell 114 277-280.

Benvenuti S, Luciani P, Vannelli GB, Gelmini S, Franceschi E, Serio M \& Peri A 2005 Estrogen and selective estrogen receptor modulators exert neuroprotective effects and stimulate the expression of selective Alzheimer's disease indicator-1, a recently discovered antiapoptotic gene, in human neuroblast long-term cell cultures. Journal of Clinical Endocrinology and Metabolism 90 1775-1782.

Bernstein L, Deapen D, Cerhan JR, Schwartz SM, LiffJ, McGann-Maloney E, Perlman JA \& Ford L 1999 Tamoxifen therapy for breast cancer and endometrial cancer risk. Journal of the National Cancer Institute 91 1654-1662.

Beyer C, Pawlak J \& Karolczak M 2003 Membrane receptors for oestrogen in the brain. Journal of Neurochemistry 87 545-550.

Biewenga E, Cabell L \& Audesirk T 2005 Estradiol and raloxifene protect cultured SN4741 neurons against oxidative stress. Neuroscience Letters 373 179-183.

Block ML, Zecca L \& Hong JS 2007 Microglia-mediated neurotoxicity: uncovering the molecular mechanisms. Nature Reviews. Neuroscience $\mathbf{8}$ $57-69$.

Brinton RD 2004 Requirements of a brain selective estrogen: advances and remaining challenges for developing a NeuroSERM. Journal of Alzheimer's Disease 6 S27-S35.

Bruce-Keller AJ, Keeling JL, Keller JN, Huang FF, Camondola S \& Mattson MP 2000 Anti-inflammatory effects of estrogen on microglial activation. Endocrinology 141 3646-3656.

Bruce-Keller AJ, Barger SW, Moss NI, Pham JT, Keller JN \& Nath A 2001 Pro-inflammatory and pro-oxidant properties of the HIV protein Tat in a microglial cell line: attenuation by 17 beta-estradiol. Journal of Neurochemistry 78 1315-1324.

Brzozowski AM, Pike AC, Dauter Z, Hubbard RE, Bonn T, Engstrom O, Ohman L, Greene GL, Gustafsson JA \& Carlquist M 1997 Molecular basis of agonism and antagonism in the estrogen receptor. Nature 389 753-758.

Buttini M, Limonta S \& Boddeke HW 1996 Peripheral administration of lipopolysaccharide induces activation of microglial cells in rat brain. Neurochemistry International 29 25-35.

Cevolani D, Bentivoglio M \& Strocchi P 2001 Glial reaction to volkensininduced selective degeneration of central neurons. Brain Research Bulletin $\mathbf{5 4}$ 353-361.

Choi JS, Park HJ, Cha JH, Chung JW, Chun MH \& Lee MY 2003 Induction and temporal changes of osteopontin mRNA and protein in the brain following systemic lipopolysaccharide injection. Journal of Neuroimmunology 141 65-73.

Ciriza I, Carrero P, Azcoitia I, Lundeen SG \& Garcia-Segura LM 2004 Selective estrogen receptor modulators protect hippocampal neurons from kainic acid excitotoxicity: differences with the effect of estradiol. Journal of Neurobiology 61 209-221. 
Combrinck MI, Perry VH \& Cunningham C 2002 Peripheral infection evokes exaggerated sickness behaviour in pre-clinical murine prion disease. Neuroscience 112 7-11.

Cunningham C, Wilcockson DC, Campion S, Lunnon K \& Perry VH 2005 Central and systemic endotoxin challenges exacerbate the local inflammatory response and increase neuronal death during chronic neurodegeneration. Journal of Neuroscience 25 9275-9284.

Cyr M, Calon F, Morissette M, Grandbois M, Di Paolo T \& Callier S 2000 Drugs with estrogen-like potency and brain activity: potential therapeutic application for the CNS. Current Pharmaceutical Design 6 1287-1312.

Depino AM, Earl C, Kaczmarczyk E, Ferrari C, Besedovsky H, del Rey A, Pitossi FJ \& Oertel WH 2003 Microglial activation with atypical proinflammatory cytokine expression in a rat model of Parkinson's disease. European Journal of Neuroscience 18 2731-2742.

Dhandapani KM \& Brann DW 2002 Protective effects of estrogen and selective estrogen receptor modulators in the brain. Biology of Reproduction 67 1379-1385.

Dimayuga FO, Reed JL, Carnero GA, Wang C, Dimayuga ER, Dimayuga VM, Perger A, Wilson ME, Keller JN \& Bruce-Keller AJ 2005 Estrogen and brain inflammation: effects on microglial expression of MHC, costimulatory molecules and cytokines. Journal of Neuroimmunology 161 123-136.

DonCarlos LL, Azcoitia I \& Garcia-Segura LM 2007 In search of neuroprotectice therapies based on the mechanisms of estrogens. Expert Review of Endocrinology and Metabolism 2 387-397.

Drew PD \& Chavis JA 2000 Female sex steroids: effects upon microglial cell activation. Journal of Neuroimmunology 111 77-85.

Du B, Ohmichi M, Takahashi K, Kawagoe J, Ohshima C, Igarashi H, MoriAbe A, Saitoh M, Ohta T, Ohishi A et al. 2004 Both estrogen and raloxifene protect against $\beta$-amyloid-induced neurotoxicity in estrogen receptor $\alpha$-transfected PC12 cells by activation of telomerase activity via Akt cascade. Journal of Endocrinology 183 605-615.

Eriksson C, Nobel S, Winblad B \& Schultzberg M 2000 Expression of interleukin $1 \alpha$ and $\beta$, and interleukin 1 receptor antagonist mRNA in the rat central nervous system after peripheral administration of lipopolysaccharides. Cytokine 12 423-431.

Feng Y, Fratkins JD \& LeBlanc MH 2004 Treatment with tamoxifen reduces hypoxic-ischemic brain injury in neonatal rats. European Journal of Pharmacology 484 65-74.

Fink G, Sumner BE, Rosie R, Grace O \& Quinn JP 1996 Estrogen control of central neurotransmission: effect on mood, mental state, and memory. Cellular and Molecular Neurobiology 16 325-344.

Garcia-Segura LM, Azcoitia I \& DonCarlos LL 2001 Neuroprotection by estradiol. Progress in Neurobiology 63 29-60.

Ghisletti S, Meda C, Maggi A \& Vegeto E 2005 17 $\beta$-Estradiol inhibits inflammatory gene expression by controlling NF- $\mathrm{\kappa B}$ intracellular localization. Molecular and Cellular Biology 25 2957-2968.

Graeber MB, Streit WJ, Kiefer R, Shoen SW \& Kreutzberg GW 1990 New expression of myelomonocytic antigens by microglia and perivascular cells following lethal motor neuron injury. Journal of Neuroimmunology 27 $121-132$

Hatton WJ \& von Bartheld CS 1999 Analysis of cell death in the trochlear nucleus of the chick embryo: calibration of the optical disector counting method reveals systematic bias. Journal of Comparative Neurology $\mathbf{4 0 9}$ 169-186.

Hauss-Wegrzyniak B, Lukovic L, Bigaud M \& Stoeckel ME 1998 Brain inflammatory response induced by intracerebroventricular infusion of lipopolysaccharide: an immunohistochemical study. Brain Research 794 211-224.

Hong SH, Choi HB, Kim SU \& McLarnon JG 2006 Mitochondrial ligand inhibits store-operated calcium influx and COX-2 production in human microglia. Journal of Neuroscience Research 83 1293-1298.

Howard CV \& Reed MG 1998 Unbiased Stereology. Three-Dimensional Measurement in Microscopy. Oxford: BIOS Scientific Publishers.

Kelly MJ, Qiu J \& Ronnekleiv OK 2005 Estrogen signaling in the hypothalamus. Vitamins and Hormones 71 123-145.

Kim SU \& de Vellis J 2005 Microglia in health and disease. Journal of Neuroscience Research 81 302-313.
Kimelberg HK, Jin Y, Charniga C \& Feustel PJ 2003 Neuroprotective activity of tamoxifen in permanent focal ischemia. Journal of Neurosurgery $\mathbf{9 9}$ $138-142$.

Klinge CM 2000 Estrogen receptor interaction with co-activators and co-repressors. Steroids 65 227-251.

Ladeby R, Wirenfeldt M, Garcia-Ovejero D, Fenger C, Dissing-Olesen L, Dalmau I \& Finsen B 2005 Microglial cell population dynamics in the injured adult central nervous system. Brain Research. Brain Research Reviews 48 196-206.

Laye S, Parnet P, Goujon E \& Dantzer R 1994 Peripheral administration of lipopolysaccharide induces the expression of cytokine transcripts in the brain and pituitary of mice. Brain Research. Molecular Brain Research 27 157-162.

Lei DL, Long JM, Hengemihle J, O’Neill J, Manaye KF, Ingram DK \& Mouton PR 2003 Effects of estrogen and raloxifene on neuroglia number and morphology in the hippocampus of aged female mice. Neuroscience $\mathbf{1 2 1}$ 659-666.

Littleton-Kearney MT, Ostrowski NL, Cox DA, Rossberg MI \& Hurn PD 2002 Selective estrogen receptor modulators: tissue actions and potential for CNS protection. CNS Drug Reviews 8 309-330.

Maggi A, Ciana P, Belcredito S \& Vegeto E 2004 Estrogens in the nervous system: mechanisms and nonreproductive functions. Annual Review of Physiology 66 291-313.

Maki PM 2005 A systematic review of clinical trials of hormone therapy on cognitive function: effects of age at initiation and progestin use. Annals of the New York Academy of Sciences 1052 182-197.

Marchetti B \& Abbracchio MP 2005 To be or not to be (inflamed) - is that the question in anti-inflammatory drug therapy of neurodegenerative disorders? Trends in Pharmacological Sciences 26 517-525.

Marin R, Guerra B, Alonso R, Ramirez CM \& Diaz M 2005 Estrogen activates classical and alternative mechanisms to orchestrate neuroprotection. Current Neurovascular Research 2 287-301.

McEwen BS, Alves SE, Bulloch K \& Weiland NG 1997 Ovarian steroids and the brain: implications for cognition and aging. Neurology 48 S8-S15.

McKenna NP \& O'Malley BO 2002 Combinatorial control of gene expression by nuclear receptors and coregulators. Cell 108 465-474.

Mehta SH, Dhandapani KM, De Sevilla LM, Webb RC, Mahesh VB \& Brann DW 2003 Tamoxifen, a selective estrogen receptor modulator, reduces ischemic damage caused by middle cerebral artery occlusion in the ovariectomized female rat. Neuroendocrinology 77 44-50.

Miller VM, Clarkson TB, Harman SM, Brinton EA, Cedars M, Lobo R, Manson JE, Merriam GR, Naftolin F \& Santoro N 2005 Women, hormones, and clinical trials: a beginning, not an end. Journal of Applied Physiology 99 381-383.

Minghetti L 2005 Role of inflammation in neurodegenerative diseases. Current Opinion in Neurology 18 315-321.

Murphy S, McCullough L, Littleton-Kearney M \& Hurn P 2003 Estrogen and selective estrogen receptor modulators: neuroprotection in the Women's Health Initiative era. Endocrine 21 17-26.

Nadeau S \& Rivest S 1999 Effects of circulating tumor necrosis factor on the neuronal activity and expression of the genes encoding the tumor necrosis factor receptors ( $\mathrm{p} 55$ and $\mathrm{p} 75$ ) in the rat brain: a view from the blood-brain barrier. Neuroscience 93 1449-1464.

Ng YK \& Ling EA 1997 Induction of major histocompatibility class II antigen on microglial cells in postnatal and adult rats following intraperitoneal injections of lipopolysaccharide. Neuroscience Research 28 111-118.

Norris JD, Paige LA, Christensen DJ, Chang CY, Huacani MR, Fan D, Hamilton PT, Fowlkes DM \& McDonnell DP 1999 Peptide antagonists of the human estrogen receptor. Science 285 744-746.

Paige LA, Christensen DJ, Grøn H, Norris JD, Gottlin EB, Padilla KM, Chang CY, Ballas LM, Hamilton PT \& McDonnell DP 1999 Estrogen receptor(ER) modulators each induce distinct conformational changes in ERa and ERb. PNAS 96 3999-4004.

Palacios S, Farias ML, Luebbert H, Gomez G, Yabur JA, Quail DC, Turbi C, Kayath MJ, Almeida MJ, Mönnig E et al. 2004 Raloxifene is not associated with biologically relevant changes in hot flushes in postmenopausal women for whom therapy is appropriate. American Journal of Obstetrics and Gynecology 191 121-131. 
Paxinos G \& Watson C 1986 The Rat Brain in Sterotaxic Coordinates. New York: Academic Press.

Pekny M \& Nilsson M 2005 Astrocyte activation and reactive gliosis. Glia 50 427-434.

Perry VH, Newman TA \& Cunningham C 2003 The impact of systemic infection on the progression of neurodegenerative disease. Nature Reviews. Neuroscience 4 103-112.

Picazo O, Azcoitia I \& Garcia-Segura LM 2003 Neuroprotective and neurotoxic effects of estrogens. Brain Research 990 20-27.

Pike AC 2006 Lessons learnt from structural studies of the oestrogen receptor. Best Practice and Research. Clinical Endocrinology and Metabolism 20 1-14.

Pitossi F, del Rey A, Kabiersch A \& Besedovsky H 1997 Induction of cytokine transcripts in the central nervous system and pituitary following peripheral administration of endotoxin to mice. Journal of Neuroscience Research $\mathbf{4 8}$ 287-298.

Polazzi E \& Contestabile A 2002 Reciprocal interactions between microglia and neurons: from survival to neuropathology. Reviews in the Neurosciences 13 221-242.

Poole T 1999 UFAW Handbook on the Care and Management of Laboratory Animals. Vol. 1 Terrestrial Vertebrates. edn 7, Oxford: Blackwell Science.

Popovich PG, Wei P \& Stokes BT 1997 Cellular inflammatory response after spinal cord injury in Sprague-Dawley and Lewis rats. Journal of Comparative Neurology 377 443-464.

Price RH \& Handa RJ 2000 Expression of estrogen receptor-beta protein and mRNA in the cerebellum of the rat. Neuroscience Letters 288 115-118.

Prokai L \& Simpkins JW 2007 Structure-nongenomic neuroprotection relationship of estrogens and estrogen-derived compounds. Pharmacology and Therapeutics $1141-12$.

Qin L, Wu X, Block ML, Liu Y, Breese GR, Hong JS, Knapp DJ \& Crews FT 2007 Systemic LPS causes chronic neuroinflammation and progressive neurodegeneration. Glia 55 453-462.

Semmler A, Okulla T, Sastre M, Dumitrescu-Ozimek L \& Heneka MT 2005 Systemic inflammation induces apoptosis with variable vulnerability of different brain regions. Journal of Chemical Neuroanatomy 30 144-157.

Shughrue PJ, Lane MV \& Merchenthaler I 1997 Comparative distribution of estrogen receptor- $\alpha$ and $-\beta$ mRNA in the rat central nervous system. Journal of Comparative Neurology 388 507-525.

Sierra A, Gottfried-Blackmore AC, McEwen BS \& Bulloch K 2007 Microglia derived from aging mice exhibit an altered inflammatory profile. Glia $\mathbf{5 5}$ $412-424$.

Sierra A, Gottfried-Blackmore A, Milner TA, McEwen BS \& Bulloch K 2008 Steroid hormone receptor expression and function in microglia. Glia $\mathbf{5 6}$ 659-674.

Stovall DW, Utian WH, Gass ML, Qu Y, Muram D, Wong M \& Plouffe L 2007 The effects of combined raloxifene and oral estrogen on vasomotor symptoms and endometrial safety. Menopause 14 510-517.
Streit WJ, Walter SA \& Pennell NA 1999 Reactive microgliosis. Progress in Neurobiology $\mathbf{5 7}$ 563-581.

Suuronen T, Nuutinen T, Huuskonen J, Ojala J, Thornell A \& Salminen A 2005 Anti-inflammatory effect of selective estrogen receptor modulators (SERMs) in microglial cells. Inflammation Research 54 194-203.

Suzuki S, Brown CM \& Wise PM 2006 Mechanisms of neuroprotection by estrogen. Endocrine 29 209-215.

Suzuki S, Brown CM, Dela Cruz CD, Yang E, Bridwell DA \& Wise PM 2007 Timing of estrogen therapy after ovariectomy dictates the efficacy of its neuroprotective and antiinflammatory actions. PNAS 104 6013-6018.

Suzumura A, Takeuchi H, Zhang G, Kuno R \& Mizuno T 2006 Roles of gliaderived cytokines on neuronal degeneration and regeneration. Annals of the New York Academy of Sciences 1088 219-229.

Takahashi N, Tonchev AB, Koike K, Murakami K, Yamada K, Yamashima T \& Inoue M 2004 Expression of estrogen receptor- $\beta$ in the postischemic monkey hippocampus. Neuroscience Letters 369 9-13.

Thomas WE 1992 Brain macrophages: evaluation of microglia and their functions. Brain Research. Brain Research Reviews 17 61-74.

Vegeto E, Bonincontro C, Pollio G, Sala A, Viappiani S, Nardi F, Brusadelli A, Viviani B, Ciana P \& Maggi A 2001 Estrogen prevents the lipopolysaccharide-induced inflammatory response in microglia. Journal of Neuroscience 21 1809-1818.

Vegeto E, Belcredito S, Etteri S, Ghisletti S, Brusadelli A, Meda C, Krust A, Dupont S, Ciana P, Chambon P et al. 2003 Estrogen receptor- $\alpha$ mediates the brain antiinflammatory activity of estradiol. PNAS 100 9614-9619.

Vegeto E, Belcredito S, Ghisletti S, Meda C, Etteri S \& Maggi A 2006 The endogenous estrogen status regulates microglia reactivity in animal models of neuroinflammation. Endocrinology 147 2263-2272.

Weibel ER 1979 Stereological Methods. Vol I. Practical Methods for Biological Morphometry. New York: Academic Press.

Woolley CS 2007 Acute effects of estrogen on neuronal physiology. Annual Review of Pharmacology and Toxicology 47 657-680.

Zhang Y, Jin Y, Behr MJ, Feustel PJ, Morrison JP \& Kimelberg HK 2005 Behavioral and histological neuroprotection by tamoxifen after reversible focal cerebral ischemia. Experimental Neurology 196 41-46.

Zuurman MW, Heeroma J, Brouwer N, Boddeke HW \& Biber K 2003 LPSinduced expression of a novel chemokine receptor (L-CCR) in mouse glial cells in vitro and in vivo. Glia 41 327-336.

Received in final form 10 April 2008

Accepted 6 May 2008

Made available online as an Accepted Preprint

7 May 2008 